\title{
Hubungan Kebiasaan Sarapan dan Asupan Kalori dengan Persentase Lemak Tubuh pada Mahasiswa Prodi Profesi Dokter Fakultas Kedokteran Universitas Andalas Angkatan 2013-2015
}

\author{
Mohammad Arraniri ${ }^{1}$, Desmawati ${ }^{2}$, Dinda Aprilia ${ }^{3}$
}

\begin{abstract}
Abstrak
Obesitas merupakan beban masalah untuk negara maju maupun negara berkembang. Beberapa faktor terjadinya obesitas adalah asupan kalori berlebih dan pola makan tidak teratur. Kebiasaan sarapan merupakan salah satu bentuk dari pola makan. Tujuan penelitian ini adalah menentukan hubungan antara kebiasaan sarapan dan asupan kalori terhadap persentase lemak tubuh. Jenis penelitian ini adalah analitik dengan pendekatan cross sectional. Sampel penelitian adalah 60 mahasiswa FK Unand. Penelitian dilaksanakan dari September sampai Desember 2016. Analisis data menggunakan uji Mann-Whitney untuk analisis bivariat $(p<0,05)$. Hasil penelitian didapatkan umur rerata responden adalah 20,05 $\pm 1,22$ tahun, 55\% memiliki kebiasaan tidak teratur, 86,7\% memiliki asupan kalori yang baik dan rerata persentase lemak tubuh sebesar $24,78 \pm 5,71$. Hasil uji bivariat didapatkan hubungan antara kebiasaan sarapan dengan persentase lemak tubuh $(p=0,001)$ dan asupan kalori dengan persentase lemak tubuh $(p=0,000)$. Simpulan penelitian ini adalah terdapat hubungan yang bermakna antara kebiasaan sarapan dan asupan kalori dengan persentase lemak tubuh.
\end{abstract}

Kata kunci: obesitas, sarapan, asupan kalori, persentase lemak tubuh

\section{Abstract}

Obesity is a problem for developed and developing countries. Some factors of obesity are excess caloric intake and eating irregularly. Breakfast habits are one form of diet. The objective of this study was to determine the relationship between breakfast habits and calorie intake on body fat percentage. This was an analytic study with cross sectional approach. Sample of this research was 60 medical students of Andalas University. The research was conducted in September - December 2016. Data were analyzed using the Mann-Whitney test for the bivariate analysis. The results showed the mean age of the sample is $20,05 \pm 1,22$ years, $55 \%$ have an eating regularly habits, $86,7 \%$ have an appropriate caloric intake and the average of body fat percentage is $24,78 \pm 5,71 \%$. The results of bivariate test showed relationship between breakfast habits with body fat percentage $(p=0.001)$ and calorie intake with body fat percentage $(p=0.000)$. The conclusion is a significant relationship between breakfast habits and calorie intake with body fat percentage.

Keywords: obesity, breakfast, calorie intake, body fat percentage

Affiliasi penulis: 1. Prodi Profesi Dokter FK Unand (Fakultas Kedokteran Universitas Andalas Padang), 2. Bagian IImu Gizi FK unand, 3. Bagian IImu Penyakit Dalam FK Unand/RSUP Dr. M. Djamil Korespondensi: Mohammad Arraniri, Email: arraniri_a7x_13@yahoo. com Telp: 085668374708

\section{PENDAHULUAN}

Obesitas saat ini merupakan masalah yang tidak hanya menjadi beban untuk negara maju, tetapi juga negara berkembang. Setidaknya 2,8 juta orang meninggal setiap tahun dikarenakan overweight dan 
obesitas. Menurut data WHO, $11 \%$ laki-laki dan 15\% wanita usia dewasa di dunia mengalami obesitas. Wilayah Asia Tenggara, hanya 3\% dari populasi yang mengalami obesitas untuk kategori laki-laki dan perempuan. $^{1,2}$

Berdasarkan hasil Riset Kesehatan Dasar (Riskesdas), didapatkan angka obesitas nasional untuk kategori usia dewasa adalah $32,9 \%$ pada perempuan dan $19,7 \%$ pada laki-lak. Obesitas di provinsi Sumatera Barat untuk laki-laki dan perempuan usia dewasa masing-masing adalah $10,5 \%$ dan $21,3 \%$. Menurut NCHS, secara global insiden tertinggi terjadinya obesitas berada pada kategori usia dewasa (18 tahun keatas) dan perempuan. ${ }^{3,4,5}$

Beberapa penyakit yang diakibatkan oleh obesitas contohnya hipertensi, diabetes, osteoarthritis dan penyakit jantung koroner. Seseorang yang mengalami obesitas akan terjadi peningkatan lemak tubuh yang dapat menjadi plak dan berujung pada hipertensi. Obesitas terjadi akibat ketidakseimbangan antara asupan kalori yang didapat dengan pengeluaran energi yang dikeluarkan. Beberapa faktor risiko obesitas adalah genetik, asupan kalori berlebih, aktivitas fisik yang kurang dan pola makan yang tidak teratur. ${ }^{6}$

Sarapan merupakan bagian dari pola makan. Definisi sarapan adalah kegiatan mengkonsumsi makanan dan minuman sebelum jam 9 pagi dan memenuhi sebagian kalori harian. Salah satu manfaat dari sarapan adalah tersedianya energi yang cukup untuk beraktivitas hingga siang hari dan apabila sarapan terlewati, seseorang akan cenderung untuk mengkonsumsi kudapan dan makanan tinggi kalori yang pada akhirnya akan berakibat pada peningkatkan kadar lemak tubuh. ${ }^{7,8}$

Asupan kalori dan kurang aktivitas fisik merupakan faktor penting terjadinya peningkatan berat badan. Perubahan pola makan masyarakat menjadi sering mengkonsumsi makanan tinggi kalori dan makanan cepat saji (fast food), meningkatkan total konsumsi energi yang berhubungan erat dengan obesitas. $^{9}$

Kelebihan lemak tubuh dapat diukur dari ketebalan pada lipatan lemak bawah kulit (subkutan) dikarenakan distribusi penumpukan lemak tubuh paling banyak terdapat di daerah subkutan yaitu sebanyak 50\%. Pengukurannya dapat dilakukan dengan menggunakan alat berupa skinfold caliper. Cara ini terbilang murah, mudah dilakukan, tidak butuh waktu lama dan tidak invasif. Untuk mendapatkan hasil yang akurat dibutuhkan kualitas skinfold caliper yang baik dan latihan yang cukup. ${ }^{10}$

Menurut penelitian, sebanyak 58,6\% mahasiswa kedokteran memiliki kebiasaan tidak sarapan, 47,1 \% jarang melakukan aktivitas fisik dengan prevalensi obesitas $9,78 \%$. Hormon seks wanita yaitu estrogen diketahui berpengaruh terhadap distribusi lemak terutama lemak subkutan pada tubuh seseorang. ${ }^{11,12,13}$ Penelitian ini bertujuan untuk menentukan hubungan kebiasaan sarapan dan asupan kalori dengan persentase lemak tubuh pada mahasiswa FK Unand.

\section{METODE}

Jenis penelitian ini adalah penelitian deskriptif observasional yang dilaksanakan pada bulan September 2016 sampai April 2017 di Fakultas Kedokteran Universitas Andalas. Populasi penelitian ini adalah seluruh mahasiswa prodi profesi dokter FK Unand angkatan 2013-2015. Sampel pada penelitian ini adalah data yang memenuhi kriteria inklusi yaitu mahasiswa yang hadir saat pengambilan data dan bersedia menandatangani lembar informed consent serta memenuhi kriteria eksklusi yaitu wanita, mengalami dehidrasi, edema dan hyperemia, sering melakukan aktivitas fisik (MET >1500), dan terdapat riwayat kegemukan. Sampel diperoleh dengan teknik simple random sampling didapat 60 responden.

\section{HASIL}

Penelitian telah dilaksanakan pada bulan Oktober 2016 hingga Januari 2017 di kampus Fakultas Kedokteran Universitas Andalas. Didapatkan 60 responden yang dapat mengikuti penelitian dan memenuhi kriteria inklusi maupun eksklusi.

\section{Karakteristik Sampel}

Semua responden pada penelitian ini adalah mahasiswa Fakultas Kedokteran Universitas Andalas 
angkatan 2013, 2014, 2015 dengan total sampel sebanyak 60 orang. Usia responden berkisar antara 18-23 tahun dengan rerata usia 20,05 tahun dengan standar deviasi $\pm 1,22$ tahun.

\section{Kebiasaan Sarapan dan Asupan Kalori}

Sebaran pasien berdasarkan karakteristik yaitu sebagai berikut.

Tabel 1. Frekuensi sarapan dan asupan kalori

\begin{tabular}{ccc}
\hline & $\mathbf{f}$ & $\%$ \\
\hline $\begin{array}{c}\text { Sarapan } \\
\text { Teratur }\end{array}$ & 27 & $45 \%$ \\
Tidak Teratur & 33 & $55 \%$ \\
Asupan Kalori & & \\
Lebih & 8 & $13,3 \%$ \\
Baik & 52 & $86,7 \%$ \\
\hline Total & 60 & $100 \%$ \\
\hline
\end{tabular}

Berdasarkan Tabel 1, sebagian besar responden memiliki kebiasaan sarapan tidak teratur dan asupan kalori sesuai kebutuhan.

\section{Persentase Lemak Tubuh}

Penelitian terhadap 60 sampel didapatkan rentang persentase lemak tubuh responden antara $8,61 \%-40,12 \%$ dengan rerata persentase sebesar $24,78 \%$ dan standar deviasi $\pm 5,71$.

\section{Hubungan Kebiasaan Sarapan dan Asupan Kalori dengan Persentase Lemak Tubuh}

Pada penelitian ini, uji normalitas data menggunakan Kolmogorov-Smirnov didapatkan data tidak berditribusi normal, sehingga digunakan uji Mann-Whitney untuk melihat korelasi antara sarapan dan asupan kalori dengan persentase lemak.

Tabel 2. Hubungan kebiasaan sarapan dan asupan kalori dengan persentase lemak tubuh

\begin{tabular}{ccc}
\hline & $\begin{array}{c}\text { Persentase Lemak } \\
\text { Tubuh } \\
\text { (Rerata } \pm \text { SD) }\end{array}$ & p \\
\hline $\begin{array}{c}\text { Sarapan } \\
\text { Teratur } \\
\text { Tidak Teratur }\end{array}$ & $22,1 \pm 4,37$ & \\
Asupan Kalori & $26,99 \pm 5,78$ & \\
Lebih & & \\
Baik & $35,15 \pm 3,72$ & 0,001 \\
\hline
\end{tabular}

Berdasarkan Tabel 3 terlihat hubungan yang bermakna antara sarapan dan asupan kalori dengan persentase lemak tubuh $(p<0,05)$.

\section{PEMBAHASAN}

Telah dilakukan penelitian pada mahasiswa Profesi Dokter Fakultas Kedokteran Universitas Andalas angkatan 2013-2015 pada bulan Oktober 2016 dengan jumlah responden sebanyak 60 orang. Sampel penelitian rata-rata berusia 20 tahun. Semua responden adalah laki-laki, karena hormon estrogen pada wanita berpengaruh terhadap distribusi lemak terutama lemak subkutan. ${ }^{13}$

Umur diduga akan berpengaruh terhadap asupan kalori dan persentase lemak tubuh. Diketahui kategori usia 19-29 tahun memiliki asupan kalori lebih banyak dengan asupan kalori harian sebesar 2725kkal per hari. Menurut Wahlqvist, meningkatnya lemak tubuh seseorang diakibatkan bertambahnya usia. Peningkatan lemak tubuh ini terjadi akibat dari penurunan aktivitas fisik. ${ }^{14}$

Berdasarkan hasil penelitian, didapatkan 55\% responden melakukan sarapan secara tidak teratur. Hasil penelitian ini tidak berbeda jauh dengan yang didapatkan oleh Larega, yaitu sebanyak 58,6\% mahasiswa di Fakultas Kedokteran Universitas Lampung melakukan sarapan secara tidak teratur. Menurut Sediaoetama, terdapat beberapa faktor yang bisa mempengaruhi kebiasaan sarapan tiap individu, yaitu perbedaan motivasi tiap individu, ekonomi, sosial budaya dan kebiasaan dalam keluarga masing-masing responden. ${ }^{12,15}$

Menurut penelitian Saufika dan Retnaningsih, bahwa kelompok acuan teman berpengaruh terhadap kebiasaan sarapan mahasiswa. ${ }^{16}$ Memiliki kebiasaan sarapan tidak teratur mengakibatkan peningkatan jumlah lemak dalam tubuh dikarenakan kecenderungan untuk mengkonsumsi kudapan dan makanan tinggi kalori. ${ }^{8}$ Mahasiswa yang memiliki kebiasaan sarapan tidak teratur dianjurkan untuk mengkonsumsi sarapan secara teratur, karena sarapan dapat memenuhi sebagian kebutuhan gizi harian dan mengurangi kecenderungan mengkonsumsi makanan tinggi kalori. 
Sebagian besar responden yang juga seorang mahasiswa memiliki asupan kalori harian yang baik. Hal ini sejalan dengan penelitian Putri bahwa rerata asupan energi makro mahasiswa FK Unand masuk kedalam kategori cukup. ${ }^{17}$ Hal ini dikuatkan dari penelitian Nurohmi dan Amalia bahwa sebagian besar mahasiswa BEM IPB memiliki tingkat kecukupan energi yang baik. ${ }^{18}$ Asupan kalori yang cukup dan bergizi seimbang berguna untuk menjaga kita tetap sehat. $^{6}$

Hasil penelitian ini menunjukkan hanya 13,3\% responden yang memiliki kalori harian berlebih. Diduga kelebihan asupan kalori pada penelitian ini karena banyak mengonsumsi kudapan tinggi lemak dan tingginya konsumsi nasi sebagai sumber karbohidrat. Kelebihan konsumsi pangan secara terus menerus akan mengakibatkan gizi lebih atau obesitas dan dapat memicu berbagai penyakit degeneratif. ${ }^{19}$

Berdasarkan hasil penelitian, didapatkan rerata persentase lemak tubuh 60 responden yang diukur dengan skinfold caliper sebesar $24,78 \%$. Penilaian persentase lemak tubuh dengan metode ini terbilang murah, mudah, tidak invasif dan singkat. Banyak metode lain yang digunakan untuk mengukur persentase lemak tubuh seseorang, seperti roentgen, CT scan, USG dan BIA. Kekurangan keempat metode tersebut selain dikarenakan biaya yang cukup tinggi, juga diakibatkan adanya radiasi pada metode roentgen dan CT scan. ${ }^{10}$

Rerata persentase lemak tubuh responden dikatakan optimal apabila masuk dalam rentang 10 $25 \%$. Terdapat $48,33 \%$ responden yang memiliki lemak tubuh berlebih dengan persentase lemak tubuh diatas $25 \%$. Berarti hampir setengah jumlah responden termasuk kategori lemak berlebih. Penimbunan lemak berlebih dapat memicu berbagai penyakit degeneratif. Hal ini sejalan dengan penelitian Handajani bahwa tingginya kadar lemak dalam tubuh bisa memicu kematian akibat tersumbatnya pembuluh darah koroner. ${ }^{19,20,21}$

Responden dianjurkan untuk melakukan aktivitas fisik. Aktivitas fisik diduga dapat mempertahankan jumlah lemak dalam tubuh, terutama olahraga aerobik. Menurut penelitian Putrama, didapatkan rerata persentase lemak atlet olahraga aerobik lebih kecil daripada atlet olahraga non aerobik. $^{22}$

\section{Hubungan Kebiasaan Sarapan dengan Persentase Lemak Tubuh}

Hasil penelitian ini menunjukkan bahwa terdapat hubungan yang bermakna antara kebiasaan sarapan dengan persentase lemak tubuh $(p<0,05)$. Penelitian ini sejalan dengan studi Jääskeläinen bahwa seseorang yang terbiasa melakukan sarapan pagi memiliki risiko peningkatan lemak tubuh lebih rendah daripada yang tidak terbiasa. ${ }^{23}$ Penelitian lain juga menguatkan bahwa salah satu faktor penting terjadinya obesitas adalah melewatkan sarapan pagi .

Hal ini berbeda dengan penelitian Mota et al bahwa melewatkan sarapan pagi tidak menjadi acuan untuk peningkatan lemak tubuh (obesitas). ${ }^{24}$ Pada kelompok penelitian tersebut menyatakan bahwa meningkatkan frekuensi makan dapat menurunkan resiko terjadi obesitas, terlepas dari seseorang tersebut sarapan atau tidak.

Perbedaan kejadian ini bisa disebabkan oleh faktor lain yang penting dalam menilai jumlah lemak tubuh seseorang yaitu tingkat aktivitas fisik. Pada kelompok yang menyatakan terdapat hubungan antara kebiasaan sarapan dengan lemak tubuh, tidak memperhatikan faktor aktivitas fisik. Pada kelompok yang menyatakan tidak terdapatnya hubungan antara kebiasaan sarapan dengan lemak tubuh seseorang tersebut melibatkan variabel aktivitas fisik.

$\mathrm{Hal}$ ini mengungkapkan bahwa untuk menghindarkan seseorang dari peningkatan lemak tubuh yang berlebih, dianjurkan untuk memiliki kebiasaan sarapan teratur dan tetap melakukan aktivitas fisik yang cukup.

\section{Hubungan Asupan Kalori dengan Persentase Lemak Tubuh}

Hasil penelitian ini menunjukkan bahwa terdapat hubungan yang bermakna antara asupan kalori dengan persentase lemak tubuh $(p<0,05)$. Hal ini sejalan dengan penelitian Sautika dan Retnaningsih yang menjelaskan bahwa jika makanan yang dikonsumsi melebihi kebutuhan akan disimpan didalam tubuh dan meningkatkan jumlah lemak dalam 
tubuh. ${ }^{25}$ Tingginya asupan kalori kemungkinan disebabkan oleh konsumsi makanan cepat saji (makanan modern) yang menjadi kebiasaan umum baik di kota besar maupun kecil di wilayah Indonesia. Secara umum, komposisi makanan jenis makanan cepat saji adalah tinggi energi, lemak, garam dan rendah serat.

Penelitian tersebut berbeda dengan penelitian Adrian et al di Amerika bahwa pengurangan asupan kalori berhubungan dengan peningkatan prevalensi obesitas. ${ }^{26}$ Perbedaan kejadian ini disebabkan oleh penelitian Adrian et al memperhatikan tingkat aktivitas fisik. Dari tahun ke tahun, semakin banyak orang yang mengkonsumsi makanan rendah lemak dan mengurangi asupan kalori tetapi mengurangi juga aktivitas fisik harian mereka.

Hal ini menjelaskan bahwa untuk menjaga tubuh terhindar dari peningkatan jumlah lemak dalam tubuh, dianjurkan untuk menjaga asupan kalori dan tetap melakukan aktivitas fisik yang cukup.

\section{SIMPULAN}

Terdapat hubungan yang bermakna antara kebiasaan sarapan dan asupan kalori dengan persentase lemak tubuh.

\section{DAFTAR PUSTAKA}

1. WHO. Global Health Observatory (GHO) data. 2008 (diunduh 2017).Tersedia dari: URL: HYPERLINK http://www.who.int/gho/ncd/ riskfactors/obesity text/en/

2. WHO. Obesity and overweight. 2015. (diunduh 2017). Tersedia dari: URL: HYPERLINK http://www.who.int/mediacentre/factsheets/fs311/ en/

3. Depkes RI. Riset kesehatan dasar. Jakarta: Depkes RI. 2013.

4. Depkes RI. Riset kesehatan dasar. Jakarta: Depkes RI. 2008.

5. Ogden CL, Carrol MD, Fryar CD, Flegal KM. Prevalence of obesity among adults and youth: United States, 2011-2014. NCHS Data Brief. 2015; 210:1-8.
6. AAAS (American Association for the Advancement of Science).2006 (diunduh 2017). Tersedia dari: URL: HYPERLINK http://ehrweb01.aaas.org/ scienceinside/files/2012/03/ObesityBookx.pdf

7. Hardiansyah. Sarapan sehat. Prosiding hasil seminar masalah dan pentingnya sarapan bagi anak. Jakarta: Pergizi Pangan Indonesia. 2012.

8. Croezen S, Visscher TLS, TerBogt NCW, Veling $\mathrm{ML}$, Haveman-Nies A. Skipping breakfast, alcohol consumption and physical inactivity as risk factors for overweight and obesity in adolescents: Results of the E-MOVO project. European Journal of Clinical Nutrition. 2009;63:405-12.

9. Rosenheck R. Fast food consumption and increased caloric intake: A systematic review of a trajectory towards weight gain and obesity risk. Obesity Reviews. 2008;9:535-47.

10. Sudibjo P. Beberapa pertimbangan dalam pemilihan metode untuk mengestimasi lemak badan. Jurnal Kardiologi Indonesia. 2011;32:14-23.

11. Miftah M. Gambaran aktivitas olahraga pada mahasiswa Fakultas Kedokteran Universitas Sumatera Utara angkatan 2011 yang menderita obesitas (skripsi). Medan: Universitas Sumatera Utara. 2011.

12. Larega TSP. Hubungan perilaku makan pagi (sarapan) dan status gizi dengan tingkat konsentrasi pada mahasiswa Fakultas Kedokteran Universitas Lampung (skripsi). Lampung, Universitas Lampung. 2015.

13. Brown LM, Clegg DJ. Central effect of estradiol in the regulation of adiposity. National Institute of Health. 2010;122:65-73.

14. Wahlqvist ML. Food and health systems in Australia and New Zealand. Sydney: Allen \& Unwin; 2011.

15. Sediaoetama AD. IImu gizi jilid II. Jakarta: PT Dian Rakyat; 2009.

16. Saufika A, Retnaningsih A. Gaya hidup dan kebiasaan makan mahasiswa. Jurnal IImu Keluarga dan Konsumen. 2012.5(2):157-65.

17. Putri VD. Hubungan pola makan dengan rasio lingkar pinggang pinggul mahasiswa pendidikan 
dokter umum Fakultas Kedokteran Universitas Andalas angkatan 2012-2014 (skripsi). Padang: Universitas Andalas; 2015

18. Nurohmi S, Amalia L. Pengetahuan gizi, aktivitas fisik dan tingkat kecukupan gizi aktivis badan eksekutif mahasiswa (BEM) IPB. Jurnal Gizi dan Pangan. 2012.7(3):151-6.

19. Beck ME. IImu gizi dan diet. Yogyakarta: Nuha Medika; 2000.

20. Firdaus $\mathrm{H}$. Hubungan konsumsi makan, umur, imt, dan aktifitas buruh laki-laki dengan persen lemak tubuh di pelabuhan Sunda Kelapa Jakarta Utara (skripsi). Jakarta: Universitas Indonesia; 2003.

21. Handajani A, Roosihermiatie B, Maryani H. Faktorfaktor yang berhubungan dengan pola kematian. Buletin Penelitian Sistem Kesehatan. 2009;13(1): 42-53.

22. Putrama R. Hubungan jenis olahraga aerobik dan anaerobik dengan tebal lipatan lemak bawah kulit pada atlet pekan olahraga wilayah Sumatera Barat tahun 2015 (skripsi). Padang: Universitas Andalas; 2015.

23. Jääskeläinen $A$, Schwab $U$, Kolehmainen $M$, Pirkola J, Järvelin MR, Laitinen J. Associations of meal frequency and breakfast with obesity and metabolic syndrome traits in adolescents of Northern Finland Birth Cohort 1986. Nutrition, Metabolism and Cardiovascular Diseases. 2013; 23(10):1002-9.

24. Mota J, Fidalgo F, Silva R, Ribeiro JC, Santos R, Carvalho J, et al. Relationships between physical activity, obesity and meal frequency in adolescents. Annals of Human Biology. 2009;35(1):1-10.

25. Saufika A, Retnaningsih A. Gaya hidup dan kebiasaan makan mahasiswa. Jurnal IImu Keluarga dan Konsumen. 2012;5(2):157-65.

26. Adrian F, Heini, Weinsier RL. Divergent trends in obesity and fat intake patterns: The american paradox. The American Journal of Medicine. 1997; 102(3):259-64. 